\title{
Information Transparency, Corporate Governance, And Convertible Bonds
}

Tsing-Zai Wu, National Cheng Kung University, Taiwan

Pin-Sheng Lee, National Cheng Kung University, Taiwan

\begin{abstract}
Information transparency is a popular topic in capital markets. A firm's corporate governance policy, which influences its disclosure behavior and disclosure quality, influences the information transparency perceived in relation to that firm. It was previously understood that greater information asymmetry between investors and issuers/underwriters translates into a larger discount required to be offered in bond pricing by the issuing firm, to attract investors. In this paper, we numerically analyze: (a) the effect of the composition of the board structure on corporate information transparency under the code law system, and (b) the effect of information transparency on the initial return rate of convertible bonds. The results of our study revealed that the board structure affects corporate information disclosure policies under the code law system. Specifically, CEO duality tends to bring about lower information transparency, whereas better information transparency emanates from a higher proportion of independent directors. However, there is a lack of conclusive evidence to support the view that the shareholdings of directors and large shareholders are correlated with information transparency. We also show numerically that greater information transparency combined with lesser information asymmetry (between insiders and outsiders) leads to a lower initial return rate of convertible bonds.
\end{abstract}

Keywords: Information Transparency; Corporate Governance; Convertible Bonds

\section{INTRODUCTION}

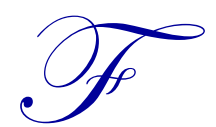

irms are required to reveal their true value in capital markets by fully disclosing their operational status in the financial statements. Concerns regarding corporate governance and information transparency have assumed staggering proportions for market investors. Although maintaining a relatively higher level of information transparency invariably leads to increased operational costs, it also enhances investors' valuation of a firm, thereby creating gains in firm value that substantially surpass the accompanying cost increases. Therefore, firms that seek financial resources to expand their business must strive to increase transparency in the disclosure of internal information. Internal transparency ensures that the firm is aware of its current situation and the manner in which it can increase its competitiveness. In contrast, external transparency leads to lower capital costs and enables firms to attract long-term investors, both of which not only benefit the firm's sustainability but also enhance investor interest. Cormier et al. (2010) found that firms consider the ultimate costs and benefits to their shareholders when determining the extent of disclosure of their governance policies and framework.

Because of the above reasons, there is a growing interest in finding ways to increase information transparency. Information transparency depends on a firm's disclosure behavior and quality, which are influenced by the firm's governance structure. Ho and Wong (2001) investigated the relationship between corporate governance policies and voluntary disclosure levels, and found that corporate governance in Hong Kong-based firms is heavily influenced by the proportion of independent directors and family members in the composition of their boards. Further, their findings indicate that corporate governance policies affect the voluntary disclosure of corporate information. Eng and Mak (2003) examined ownership structure and board composition of Singaporean firms and their relationship with the voluntary information disclosure behavior of those firms. Their results indicated that ownership structure and board composition influence information disclosure. Hermalin and Weisbach (2012) found that larger firms adopt stricter disclosure rules than smaller firms, and firms with better disclosure employ management that is more competent. 
Previous studies have also found that the structure and characteristics of corporate governance in a country are influenced by its economic, social, political, legal, and historical background. Ball et al. (2000) noted that the shareholder's equity model is adopted for corporate governance in common law countries such as the United Kingdom and the United States. Under this model, employees are concerned with maximizing the firm's interests. In contrast, code law countries (e.g., Germany, Japan, and Taiwan) typically employ the stakeholder model for corporate governance. Under this model, employees are more concerned with the protection of their employment rights including the right to participate in corporate decision-making. The greatest difference between these two models is in the treatment of information asymmetry between the internal firm employees and external stakeholders. In common law countries, designating independent directors in firms upholds increased information transparency and eliminates information asymmetry. However, it remains unclear as to whether the corporate governance system that is practiced in common law countries can be implemented in code law countries such as Taiwan to improve information transparency. This study endeavored to determine how corporate governance in code law countries, which differs from that in common law countries such as the United States, influences corporate information disclosure, and examined the relationship between domestic board structure and corporate information transparency.

Previous studies have identified and confirmed the existence of abnormal returns from initial public offerings (IPOs). Abnormal returns generally result from underpricing of offerings by the issuing firm. Researchers have broadly summarized three explanations to analyze IPO underpricing: information asymmetry (Ritter \& Welch, 2002), information transmission theory (Aggarwal et al., 2002), and investor overreaction (Adams et al., 2008). Specifically, with regard to information asymmetry, the greater the degree of information asymmetry between investors and issuers or underwriters, the larger the discount offered by the issuing firm to attract investors. Since convertible bonds possess the characteristics of both bonds and stocks, this also generates a phenomenon analogous to the situation of abnormal returns during initial issuances (Cai et al., 2007). Consequently, this study also aims to explore whether the initial return rate variability decreases with information transparency during the initial issuance of convertible bonds.

Based on the above assertions, the aims of this study were as follows: (a) To explore the effect of board structure composition on corporate information transparency under the code law system. Board structure comprises the percentage of director shareholding, CEO duality, percentage of large shareholding, and independent directorship. (b) To investigate the effect of information transparency on the initial return rate of convertible bonds. Our results show that under the code law system, board structure affects corporate information disclosure policies. Specifically, CEO duality tends to lead to lower information transparency, whereas better information transparency emanates from a higher proportion of independent directors. However, there is no clear evidence that shareholdings of directors and large shareholders are correlated with information transparency. We also show numerically greater information transparency and lesser information asymmetry (between insiders and outsiders) leads to a lower initial return rate of convertible bonds.

\section{HYPOTHESIS DEVELOPMENT}

\section{Information Transparency and Board Structure}

According to the interest convergence hypothesis, the percentage of board shareholding is positively correlated with corporate performance. When board shareholding exceeds a certain level, board wealth is related to corporate performance; therefore, when the board's interests converge with the firm's interests, the board exerts its supervisory effect to prevent managers from making decisions that may jeopardize the firm's interests. Lin et al. (2013) noted that a higher director shareholding rate enhances firm accounting performance, implying that directors with greater shareholding exhibit the intention of greater supervision, thus minimizing agency problems and improving operational performance. In addition, Cheung et al. (2011) use time-series data to examine the relation between changes in the quality of corporate governance practices and subsequent market valuation among large listed companies in Hong Kong. They reported that voluntary disclosures of proprietary information enable the capital market to evaluate the securities issued by firms more accurately, and provided evidence to support the notion that good corporate governance can predict future market valuation. Thus, to stimulate positive valuations from creditors and investors, firms with a satisfactory governance mechanism and operational performance have greater incentives to disclose information compared to firms exhibiting poor performance or low corporate governance. Based on these arguments, the following hypothesis is proposed: 
[H1] A high percentage of director shareholding is associated with relatively greater information transparency.

Numerous studies (e.g., Bliss, 2010; Ramdani \& Witteloostuijn, 2010) have reported that the board of directors serves as a supervisory mechanism for shareholders to monitor and control the decision-making behavior of management. In the event of CEO duality, the CEO-cum-board chairperson simultaneously serves as an executive and supervisory unit for decision-making, and thus, is likely to manipulate the board for personal interests, resulting in shareholders questioning the impartiality of the board regarding management supervision. Consequently, CEO duality often generates concerns related to conflict of interest and the inability to objectively assess management performance. Sharma (2004) found that CEO duality may interfere with board resolutions, rendering the objective of control and management of decision-making processes difficult, thereby weakening supervisory functions. Consequently, the agency costs between shareholders and managers increase, negatively affecting firm performance. Geletkanycz and Boyd (2011) also found that CEOs outside directorships are positively related to the long-term performance of firms facing competitive constraints on growth. Kang and Kim (2011) note that management could influence reported earnings by making accounting choices or operating decisions discretionally, showing that firms with CEO duality are more prone to earnings management problem, increasing the likelihood of fraud. Therefore, we speculate that for firms with CEO duality, decisions tend to be biased or made according to the CEO's personal interests, which reduces the level of information disclosure and thus, compromises the firm's information transparency. Based on these arguments, we proposed a second hypothesis as follows:

[H2] CEO duality is associated with reduced information transparency.

Compared with retail investors, whose shareholding percentage is relatively low and equities are dispersed, major shareholders have a greater incentive to engage in management supervision, and the resources to cover the associated costs and expenses. Under certain circumstances, they may even directly participate in business management to resolve information asymmetries between internal management and external shareholders. The findings reported by Attig et al. (2009) indicate that when firm ownership is concentrated, major shareholders can exert effective control on a firm's operating policies, or recommend appropriate strategies to promote firm value. In such cases, major shareholders exploit their dominant voting rights to influence managerial decision-making and avoid unfavorable investment plans. Chuang (2007) examined the effect that external major shareholders and pre-managed earning shortages exert on earnings management, and found that shareholdings of large external shareholders and large external corporate shareholders have a significantly negative effect on discretionary accruals and discretionary working capital accruals, and these effects can be leveraged to improve corporate governance. Therefore, to maximize shareholder wealth, ownership concentrated among major shareholders may generate relatively greater incentives for firm monitoring and prompt the disclosure of more information, thereby improving information transparency. Accordingly, we proposed the following hypothesis:

[H3] A large shareholder with high percentage of shares is associated with high information transparency.

Sharma (2004) identified that when the proportion of independent directors in a board increases, incidents of fraud in financial statements decline, demonstrating the importance of board structure in corporate governance. Linck et al. (2008) also highlighted an emerging trend regarding the number of seats for corporate board of directors, that is, an increase and decrease in the number of seats for independent and internal directors, respectively. Since an increase in the number of independent director seats ensures that board decisions are made with greater objectivity and impartiality, agency conflicts are also minimized. Ferreira et al. (2011) showed a positive relationship between the proportion of independent directors and the firms' accounting quality and earning informativeness. In Taiwan, Yeh et al. (2004) confirmed that firms with independent directors receive superior market evaluations than firms without independent directors. This is because the appointment of independent directors signals the firm's willingness to receive supervision; thus, information asymmetry is reduced, yielding positive effects for the firm. Regarding the information asymmetry hypothesis, we speculate that more the number of independent director seats in a board, more is the information disclosed by the firm; thus, the firm's information transparency is expected to be relatively greater. Accordingly, we proposed the following hypothesis:

[H4] A high proportion of independent directors in a board ensure relatively greater information transparency. 


\section{Convertible Bonds and Information Transparency}

The IPO underpricing anomaly shows that new shares appear to be issued with a discount on the true value. Ibbotson (1975) was the first to test this kind of anomaly, and he confirmed the phenomenon of IPO underpricing. Subsequently, researchers worldwide have verified excess returns on initial issuances in various markets. Agathee et al. (2012) highlighted that IPO underpricing is triggered by the uncertainty experienced by investors because of information asymmetries between investors and issuing firms. Moreover, uncertainty is positively correlated with the magnitude of underpricing; in other words, stocks with higher uncertainty are likely to receive greater discounts. Therefore, excess returns occur because of underpriced sales by the issuing firm. Issuances are underpriced to compensate for investors' possible losses arising from information asymmetry. They also showed that the hot IPO issues markets exhibit, on an average, a greater degree of underpricing than the cold IPO issues markets.

Convertible bonds possess the characteristics of both stocks and bonds. Cai et al. (2007) examined underpricing of initial public offerings in the corporate bond market. They found that underpricing occurs with IPOs and is highest among riskier, unknown firms. They offered evidence suggesting that information problems drive underpricing, with support for both the bookbuilding view of underpricing and the asymmetric information theory. Additionally, they showed that initial issuances of convertible bonds also involve excess returns. Hsieh (2011) argued that potential arbitrage opportunities exist in Taiwan's convertible bonds market because of its inherent imperfection and inefficiency. If the occurrence of excess returns is analogous to the asymmetric property of IPO information, we hypothesize that firms with relatively greater information transparency exhibit less variations in the initial returns of convertible bond. Thus, we proposed the following hypothesis:

[H5] High corporate information transparency indicates low changes in the initial return rate of convertible bonds.

\section{RESEARCH DESIGN}

\section{Sample}

The subjects of this study were listed and over-the-counter (OTC) companies in Taiwan. Data was retrieved from the Taiwan Economic Journal (TEJ), Securities and Futures Institute, and the information-disclosure evaluation system of Securities and Futures Institute. Since 2003, the information disclosure and evaluation system of the Securities and Futures Institute has only included firms with relatively high information transparency. In 2005, the Institute evaluated companies on a 5-level Grade (A+, A-, B, C, and C-). The ninth evaluation was performed in 2011, during which the Institute divided the evaluation result on a 7-level Grade (A++, A+, A, A-, B, C, and C-) to enhance the level based on which information disclosure of evaluated firms can be distinguished. To extensively investigate the effects that various evaluation levels exert on convertible bonds, this study excluded data from 2003 to 2004 during which the evaluation level system was not implemented. Therefore, the data included in this study are from 2005 to 2012. In addition, the research samples were selected according to the following four criteria:

1. All listed and OTC firms in Taiwan's securities market, which had issued unsecured domestic convertible bonds during the research period.

2. Sample data must contain complete variables for the research period; incomplete data was eliminated.

3. Financial and insurance firms are excluded from the research sample because their services differ from those offered by other industries.

4. Firms that are associated with full-cash delivery and managed stocks were excluded from this study because they exhibit unique financial structures and employ differing transaction methods.

Based on the aforementioned sample selection criteria, there are 341 final valid samples.

\section{Models}

This study first analyzed the relationship between information transparency and the board structure. Because credit ratings may affect a firm's willingness to disclose information, this study also considered firm credit 
rating. Additionally, different levels of information transparency may exist in various board structures. Therefore, based on information disclosure evaluation result of the Securities and Futures Institute, this study divided the samples into three categories, namely, Levels A, B, and C, to further analyze the relationship between different levels of information transparency and the board structure. Subsequently, empirical testing using logistic regression was performed as follows:

Model 1: Analyzing the correlation between corporate information transparency and the board structure

$\operatorname{TRANSPA}_{i, t}=\alpha_{0}+\alpha_{1} \operatorname{TCRI}_{i, t}+\alpha_{2} \operatorname{SHARE}_{i, t}+\alpha_{3} \operatorname{CHAIRM}_{i, t}+\alpha_{4}$ BLOCK $_{i, t}+\alpha_{5} \operatorname{IND}_{i, t}+\alpha_{6} \mathrm{ASSET}_{i, t}+\varepsilon_{i, t}$

where TRANSPA is a dummy variable of information transparency, TCRI is credit rating, SHARE is board shareholding, CHAIRM is CEO duality, BLOCK is shareholding of large shareholders, IND is the ratio of independent directors, and ASSET is firm size.

In addition, considering the three sample groups, this study also examined the effect that various levels of information transparency have on the initial return rate for convertible bonds using the ordinary least squares (OLS) method. Thus, Model 2 is described as follows:

Model 2: Analyzing the correlation between convertible bonds and corporate information transparency

$$
\operatorname{RETURN}_{i, t}=\beta_{0}+\beta_{1} \text { TRANSPA }_{i, t}+\beta_{2} \text { MARKET }_{i, t}+\beta_{3} A G E_{i, t}+\beta_{4} G R O W_{i, t}+\beta_{5} S A L E_{i, t}+\beta_{6} L E V_{i, t}+\varepsilon_{i, t}
$$

where RETURN is initial return rate of convertible bonds, TRANSPA is a dummy variable of information transparency, MARKET is public offering market, $A G E$ is establishment time, GROW is growth opportunities, SALE is firm size, and $L E V$ is financial leverage.

\section{Variable Definitions}

Each operational variable included in the empirical model is defined as follows:

\section{Information Transparency (TRANSPA)}

In this study, the evaluation results obtained from the information-disclosure evaluation system were used as proxy variables to evaluate the transparency of corporate information. Information-disclosure evaluations are performed annually. Indicators of the information-disclosure evaluation system can be grouped into the following five categories: legal compliance, timeliness of information disclosure, disclosure of predictive financial information, disclosure of annual reports, and disclosure of website information. Based on the evaluation results provided by the information-disclosure evaluation system established by the Securities and Futures Institute, the research samples were divided into three groups, namely, (a) Level A, Grade above A-, (b) Level B, Grade equal B, and (c) Level C, Grade under C.

\section{Initial Return Rate of Convertible Bonds (RETURN)}

In addition to the prices of underlying stock, the trading prices of convertible bonds are influenced by factors such as interest rate fluctuations. To eliminate other confounding factors, the closing price on the first trading day was set as the initial return rate. However, given the constraints associated with market regulations (e.g., price increase/decrease), if the closing price on the first trading day reaches the upper or lower limit, the closing price of the second trading day is selected as the initial return rate. This also applies when the closing price of the second trading day reaches its upper or lower limit.

\section{Credit Rating (TCRI)}

Credit ratings refer to the evaluation of a firm's credit status or solvency. The Taiwan Corporate Credit Risk Index (TCRI) maintained by the TEJ was used as the proxy variable. TCRI credit ratings can range between Grades 
1 and 9 , where a smaller grade signifies a superior credit rating, and a grade of 10 indicates financial crisis for the firm evaluated.

Board Shareholding (SHARE)

Board shareholding is calculated as the number of director shares at the end of the financial year divided by the total number of outstanding shares. When the number of shares a director possesses is high and its interests converge with the firm's interests, the director may exert a supervisory effect on the firm to minimize agency problems.

\section{CEO Duality (CHAIRM)}

CEO duality may reduce the level of management discipline, which jeopardizes the mechanism of corporate governance. Thus, CEO duality serves as a dummy variable, where 1 indicates CEO duality and 0 represents otherwise.

Shareholding of Large Shareholders (BLOCK)

Large shareholders are defined as those holding at least 10\% of a firm's shares (Taiwan Stock Exchange) or, according to various annual reports and prospectuses, those who possess the top 10 highest number of shares or more than 5\% of shares. In this study, the number of shares that a large shareholder possesses is calculated by summing the number of shares possessed by large shareholders (according to the Taiwan Stock Exchange); primary shareholders, as disclosed in annual reports and prospectuses; and shareholders that are ranked in the top 10. Shareholders acting as a director or manager were not included in the calculations.

\section{Ratio of Independent Directors (IND)}

Independent directors are defined as those who (a) do not work for the firm, (b) have no consanguinity relationship with directors, and (c) possess shares less than $1 \%$ when elected as an independent director. Therefore, the independent director ratio is calculated as the total number of independent director seats divided by the number of director seats.

\section{Firm Size (ASSET and SALE)}

In this study, the natural logarithm of a firm's total assets was used as the proxy variable (ASSET) to denote firm size. We anticipated that large firms experience greater pressures and must disclose more information, thus exhibiting higher information transparency. In addition, the natural logarithm of net sales (SALE) was used as a proxy variable for firm size.

\section{Public Offering Market (MARKET)}

In public offering markets, a dummy variable of 1 indicates that trading was conducted in the Taiwan Stock Exchange and 0 denotes otherwise. Of the 341 samples obtained in this study, 197 were traded in the Taiwan Stock Exchange, and 144 were traded in the Gre Tai Securities Market. The greatest difference between the two markets is that the Taiwan Stock Exchange is a centralized trading market of a comparatively larger scale with higher liquidity, whereas the Gre Tai Securities Market is maintained for OTC trading, size and liquidity of which are substantially smaller. Therefore, for a specific bond, different trading markets signify different liquidity. Convertible bonds with lower liquidity require a higher rate of return as compensation. Classifying according to different trading markets, we hypothesize that the convertible bonds traded in centralized markets have relatively lower excess returns, whereas those traded in OTC markets have comparatively higher excess returns.

\section{Establishment Time (AGE)}

The establishment time is counted from the day of firm founding to the day of convertible bond issuance. At the initial stage of convertible bond issuance, information asymmetry exists between the issuing firm and the 
investors. The longer the firm is established, the more the market understands the operational situation. Therefore, to investigate whether a correlation exists between the initial return rate of convertible bonds and information transparency, this study used the establishment time as a control variable.

\section{Growth Opportunities (GROW)}

Firms with higher growth opportunities possess superior profitability prospects and higher stock returns, which subsequently affect the trading price of convertible bonds. In this study, the ratio of market equity to book equity was used as a proxy variable for growth opportunities.

\section{Financial Leverage (LEV)}

Financial leverage was calculated by dividing the total liabilities of a firm at the end of the year with the total assets. When deciding whether to purchase a firm's convertible bonds, investors consider the firm's capital structure in addition to the converted prices of the underlying bonds. If the firm's debt ratio is high, the investors face greater investment risks, which reduce their willingness to invest.

\section{RESULTS}

\section{Descriptive Statistics}

Table 1 shows descriptive statistics of our sample on the information disclosure and transparency ranking results, for which data period is from 2005 to 2012. In our study, 341 companies issued convertible bonds from 2005 to 2012. In the 341 listed companies of our sample, 1 company is ranked as "Grade A++," 11 companies are ranked as "Grade A+," 4 companies are ranked as "Grade A," 64 companies are ranked as "Grade A-," 199 companies are ranked as "Grade B," 56 companies are ranked as "Grade C," and 6 companies are ranked as "Grade C-." Level A companies ranked as Grade above A- are 80 in number, or $23.46 \%$ of the samples. Level B companies ranked Grade $\mathrm{B}$ are 199 in number, or $58.36 \%$ of the samples. Level C companies ranked as Grade under C are 62 , or $18.18 \%$ of the samples.

Table 1: Information Disclosure and Transparency Ranking Results

\begin{tabular}{|c|c|c|c|c|c|c|c|c|}
\hline & \multicolumn{4}{|c|}{ Level A } & \multirow{2}{*}{$\begin{array}{c}\text { Level B } \\
\text { B }\end{array}$} & \multicolumn{2}{|c|}{ Level C } & \multirow{2}{*}{ Tota } \\
\hline & $\mathbf{A}++$ & $\mathbf{A +}$ & $\mathbf{A}$ & A- & & $\mathbf{C}$ & C- & \\
\hline 2005 & $*$ & 0 & $*$ & 5 & 8 & 4 & 0 & 17 \\
\hline 2006 & $*$ & 1 & * & 11 & 32 & 4 & 1 & 49 \\
\hline 2007 & $*$ & 0 & $*$ & 2 & 28 & 11 & 2 & 43 \\
\hline 2008 & $*$ & 0 & * & 3 & 15 & 1 & 1 & 20 \\
\hline 2009 & $*$ & 2 & * & 10 & 22 & 5 & 0 & 39 \\
\hline 2010 & $*$ & 3 & * & 14 & 26 & 11 & 2 & 56 \\
\hline 2011 & 1 & 3 & 2 & 10 & 38 & 14 & 0 & 67 \\
\hline 2012 & 0 & 2 & 2 & 9 & 30 & 6 & 0 & 49 \\
\hline Total & 1 & 11 & 4 & 64 & 199 & 56 & 6 & 341 \\
\hline
\end{tabular}

Note: In 2005, the Securities and Futures Institute evaluated companies on a 5-level Grade (A+, A-, B, C, and C-). The ninth evaluation was performed in 2011, in which the Institute divided the evaluation result on a 7-level Grade (A++, A+, A, A-, B, C, and C-) to enhance the level based on which the information disclosure of evaluated firms can be distinguished.

Table 2 presents descriptive statistics of our sample and variables, for which data period is from 2005 to 2012. The mean of initial return rate of convertible bonds $\left(R E T U R N_{i, t}\right)$ is 8.12 , and its median is 7.87 , showing that the convertible bonds of most companies at the initial return rate of convertible bonds are positive. The maximum credit rating $\left(T C R I_{i, t}\right)$ is 9.00 , showing that the companies will issue convertible bonds to raise capital or improve the financial structure despite a financial crisis. The mean of shareholding of large shareholders $\left(B L O C K_{i, t}\right)$ is 16.41 , and the mean of ratio of independent directors $\left(I N D_{i, t}\right)$ is 0.31 . In addition, the mean of CEO duality is 0.35 , indicating that $35 \%$ of the company chairmen are also CEOs in our sample. The average establishment time $\left(A G E_{i, t}\right)$ is 10.62 , its medium is 9.00, and its maximum is 39.00, depicting that the younger companies require higher capital, and convertible bonds are the main sources of financing for them. 
Table 2: Descriptive Statistics

\begin{tabular}{|c|c|c|c|c|c|}
\hline Variable & Mean & Medium & Maximum & Minimum & Sta. Dev. \\
\hline$R E T U R N_{i, t}$ & 8.12 & 7.87 & 28.62 & -3.00 & 6.81 \\
\hline$T C R I_{i, t}$ & 5.66 & 5.00 & 9.00 & 1.00 & 1.30 \\
\hline$S H A R E_{i, t}$ & 23.39 & 18.13 & 67.33 & 5.02 & 11.89 \\
\hline CHAIRM $_{i, t}$ & 0.35 & 0.00 & 1.00 & 0.00 & 0.48 \\
\hline$B L O C K_{i, t}^{i, t}$ & 16.41 & 16.51 & 40.22 & 0.00 & 8.74 \\
\hline$I N D_{i, t}$ & 0.31 & 0.38 & 0.67 & 0.20 & 0.14 \\
\hline$A S S E T_{i, t}$ & 16.43 & 16.38 & 24.52 & 12.11 & 1.89 \\
\hline$M A R K E T_{i, t}$ & 0.58 & 0.00 & 1.00 & 0.00 & 0.49 \\
\hline$A G E_{i}$ & 10.62 & 9.00 & 39.00 & 6.00 & 6.12 \\
\hline$G R O W_{i}$ & 2.51 & 1.89 & 7.31 & 0.58 & 1.61 \\
\hline$S A L E_{i}$ & 17.45 & 17.87 & 23.36 & 12.21 & 1.88 \\
\hline$L E V_{i}$ & 40.32 & 44.35 & 78.14 & 13.10 & 14.81 \\
\hline
\end{tabular}

Note: 1 . Number of observations $=341.2$. Variable definitions: RETURN is initial return rate of convertible bonds. TCRI is credit rating. SHARE is board shareholding. CHAIRM is CEO duality. BLOCK is shareholding of large shareholders. IND is the ratio of independent directors. ASSET is firm size. MARKET is public offering market. AGE is establishment time. GROW is growth opportunities. SALE is firm size. $L E V$ is financial leverage. 3. "Sta. Dev." denotes Standard Deviation.

\section{Corporate Information Transparency and Construction of the Board}

\section{Pearson Correlation Analysis of Corporate Information Transparency and Construction of the Board}

To find out whether the level of information transparency is related to different Board constructions, based on the information disclosure and evaluation system of the Securities and Futures Institute, this thesis dissects the samples into three groups: Level A, Level B, and Level C. Tables 3-1, 3-2, and 3-3 present the related Pearson analysis of the transparency of information and construction of the Board. The results of information transparency disclosure rankings of TRANSPA Th $_{i, t}$ Table 3-1 represent its Level A as 1 and Level B as 0; in Table 3-2, Level B is represented as 1 and Level $\mathrm{C}$ as 0; in Table 3-3, Level $\mathrm{A}$ is represented as 1 and Level $\mathrm{C}$ as 0.

Table 3-1: Pearson Correlation Analysis of Corporate Information Transparency and Construction of the Board (TRANSPA is a dummy variable of information transparency, which takes 1 if Level $A$, and 0 if Level B)

\begin{tabular}{|c|c|c|c|c|c|c|c|}
\hline & $\operatorname{TRANSPA}_{i, t}$ & $T C R I_{i, t}$ & $\overline{S H A R E_{i, t}}$ & CHAIRM $_{i, t}$ & $\overline{B L O C K_{i, t}}$ & $I N D_{i, t}$ & $\overline{A S S E T_{i, t}}$ \\
\hline $\operatorname{TRANSPA}_{i, t}$ & 1.000 & & & & & & \\
\hline$T C R I_{i, t}$ & $\begin{array}{c}-0.179^{\text {*** }} \\
(0.043)\end{array}$ & 1.000 & & & & & \\
\hline$S H A R E_{i, t}$ & $\begin{array}{c}0.087 \\
(0.213)\end{array}$ & $\begin{array}{l}-0.084 \\
(0.201)\end{array}$ & 1.000 & & & & \\
\hline CHAIRM $_{i, t}$ & $\begin{array}{l}-0.039 \\
(0.348)\end{array}$ & $\begin{array}{c}0.158^{*} \\
(0.068)\end{array}$ & $\begin{array}{l}-0.091 \\
(0.192)\end{array}$ & 1.000 & & & \\
\hline$B L O C K_{i, t}$ & $\begin{array}{l}-0.127^{*} \\
(0.079)\end{array}$ & $\begin{array}{c}0.128 \\
(0.112)\end{array}$ & $\begin{array}{l}-0.017 \\
(0.429)\end{array}$ & $\begin{array}{c}0.067 \\
(0.254)\end{array}$ & 1.000 & & \\
\hline$I N D_{i, t}$ & $\begin{array}{l}-0.025 \\
(0.348)\end{array}$ & $\begin{array}{c}0.122 \\
(0.171)\end{array}$ & $\begin{array}{l}0.193^{* * *} \\
(0.034)\end{array}$ & $\begin{array}{c}-0.241^{* *} \\
(0.018)\end{array}$ & $\begin{array}{c}0.081 \\
(0.227)\end{array}$ & 1.000 & \\
\hline $\boldsymbol{A S S E T}_{i, t}$ & $\begin{array}{l}0.233^{* * *} \\
(0.019)\end{array}$ & $\begin{array}{l}-0.599^{* * * *} \\
(<0.001)\end{array}$ & $\begin{array}{c}0.088 \\
(0.177)\end{array}$ & $\begin{array}{c}0.066 \\
(0.270)\end{array}$ & $\begin{array}{l}-0.388^{* * * *} \\
(<0.001)\end{array}$ & $\begin{array}{c}-0.363^{* * *} \\
(0.001)\end{array}$ & 1.000 \\
\hline
\end{tabular}

Note: 1 . Number of observations $=279.2{ }^{*}$, **, and $* * *$ denote significance beyond 10 percent, 5 percent, and 1 percent levels, respectively. 3 . Variable definitions: TRANSPA is a dummy variable of information transparency, which takes 1 if Level A, and 0 if Level B. TCRI is credit rating, SHARE is board shareholding, CHAIRM is CEO duality, BLOCK is shareholding of large shareholders, IND is the ratio of independent directors, and ASSET is firm size.

The significant negative correlation between $T R A N S P A_{i, t}$ and $T C R I_{i, t}$ in Table 3-1 and Table 3-3 indicates a worse state of information transparency for companies in financial crisis. The significant negative correlation between TRANSPA ${ }_{i, t}$ and BLOCK significant positive correlation between $T R A N S P A_{i, t}$ and $I N D_{i, t}$ in Table 3-2 is consistent with the hypothesis that the higher the number of seats for independent directors, the better the corporate governance and information transparency of the company. There is significant positive correlation between $A S S E T_{i, t}$ and $T_{R A N S P A_{i, t}}$ in Table 3-1 and Table 3-3, which indicates that the bigger the company, the better is its information transparency. However, 
$S H A R E_{i, t}$ and CHAIRM $_{i, t}$ are not significant in the tables on Pearson related analysis and in the statistics, and as a result, only hypothesis 4 is supported in this part.

Table 3-2: Pearson Correlation Analysis of Corporate Information Transparency and Construction of the Board (TRANSPA is a dummy variable of information transparency, which takes 1 if Level $\mathrm{B}$, and 0 if Level C)

\begin{tabular}{|c|c|c|c|c|c|c|c|}
\hline & $T_{R A N S P A_{i, t}}$ & $T C R I_{i, t}$ & $S H A R E_{i, t}$ & CHAIRM $_{i, t}$ & $B L O C K_{i, t}$ & $I N D_{i, t}$ & $A S S E T_{i, t}$ \\
\hline$T R A N S P A_{i, t}$ & 1.000 & & & & & & \\
\hline $\operatorname{TCRI}_{i, t}$ & $\begin{array}{c}0.004 \\
(0.482)\end{array}$ & 1.000 & & & & & \\
\hline$S H A R E_{i, t}$ & $\begin{array}{l}-0.055 \\
(0.306)\end{array}$ & $\begin{array}{l}-0.094 \\
(0.182)\end{array}$ & 1.000 & & & & \\
\hline CHAIRM $_{i, t}$ & $\begin{array}{c}-0.093 \\
(0.194)\end{array}$ & $\begin{array}{c}-0.222^{* *} \\
(0.019)\end{array}$ & $\begin{array}{l}-0.106 \\
(0.124)\end{array}$ & 1.000 & & & \\
\hline BLOCK $_{i, t}$ & $\begin{array}{l}-0.041 \\
(0.342)\end{array}$ & $\begin{array}{c}0.070 \\
(0.254)\end{array}$ & $\begin{array}{l}-0.005 \\
(0.489)\end{array}$ & $\begin{array}{c}0.119 \\
(0.131)\end{array}$ & 1.000 & & \\
\hline$I N D_{i, t}$ & $\begin{array}{l}0.176^{*} \\
(0.052)\end{array}$ & $\begin{array}{c}0.022 \\
(0.431)\end{array}$ & $\begin{array}{l}0.209^{\text {*** }} \\
(0.017)\end{array}$ & $\begin{array}{c}-0.180^{* *} \\
(0.044)\end{array}$ & $\begin{array}{c}-0.042 \\
(0.354)\end{array}$ & 1.000 & \\
\hline $\operatorname{ASSET}_{i, t}$ & $\begin{array}{c}0.021 \\
(0.429)\end{array}$ & $\begin{array}{l}-0.595^{* * * *} \\
(<0.001)\end{array}$ & $\begin{array}{c}-0.120 \\
(0.134)\end{array}$ & $\begin{array}{l}-0.149^{*} \\
(0.072)\end{array}$ & $\begin{array}{c}-0.207^{* * *} \\
(0.024)\end{array}$ & $\begin{array}{c}-0.215^{* *} \\
(0.020)\end{array}$ & 1.000 \\
\hline
\end{tabular}

Note: 1 . Number of observations $=261.2{ }^{*}, * *$, and $* * *$ denote significance beyond 10 percent, 5 percent, and 1 percent levels, respectively. 3 . Variable definitions: TRANSPA is a dummy variable of information transparency, which takes 1 if Level $\mathrm{B}$, and 0 if Level C. TCRI is credit rating, SHARE is board shareholding, CHAIRM is CEO duality, BLOCK is shareholding of large shareholders, IND is the ratio of independent directors, and ASSET is firm size.

Table 3-3: Pearson Correlation Analysis of Corporate Information Transparency and Construction of the Board (TRANSPA is a dummy variable of information transparency, which takes 1 if Level $\mathrm{A}$, and 0 if Level C)

\begin{tabular}{|c|c|c|c|c|c|c|c|}
\hline & $T_{R A N S P A_{i, t}}$ & $T C R I_{i, t}$ & $S H A R E_{i, t}$ & CHAIRM $_{i, t}$ & $\mathrm{BLOCK}_{i, t}$ & $I N D_{i, t}$ & $\boldsymbol{A S S E T}_{i, t}$ \\
\hline$T R A N S P A_{i, t}$ & 1.000 & & & & & & \\
\hline$T C R I_{i, t}$ & $\begin{array}{l}-0.245^{*} \\
(0.061)\end{array}$ & 1.000 & & & & & \\
\hline$S H A R E_{i, t}$ & $\begin{array}{c}0.059 \\
(0.317)\end{array}$ & $\begin{array}{c}0.094 \\
(0.281)\end{array}$ & 1.000 & & & & \\
\hline CHAIRM $_{i, t}$ & $\begin{array}{l}-0.152 \\
(0.172)\end{array}$ & $\begin{array}{c}0.118 \\
(0.231)\end{array}$ & $\begin{array}{c}-0.092 \\
(0.280)\end{array}$ & 1.000 & & & \\
\hline $\boldsymbol{B L O C K}_{i, t}$ & $\begin{array}{l}-0.196 \\
(0.110)\end{array}$ & $\begin{array}{c}0.073 \\
(0.328)\end{array}$ & $\begin{array}{l}-0.152 \\
(0.170)\end{array}$ & $\begin{array}{l}-0.097 \\
(0.269)\end{array}$ & 1.000 & & \\
\hline$I N D_{i, t}$ & $\begin{array}{c}0.177 \\
(0.131)\end{array}$ & $\begin{array}{c}0.159 \\
(0.162)\end{array}$ & $\begin{array}{c}0.011 \\
(0.468)\end{array}$ & $\begin{array}{c}0.157 \\
(0.175)\end{array}$ & $\begin{array}{c}0.001 \\
(0.500)\end{array}$ & 1.000 & \\
\hline $\operatorname{ASSET}_{i, t}$ & $\begin{array}{l}0.287^{* * *} \\
(0.034)\end{array}$ & $\begin{array}{c}-0.391^{* * * *} \\
(0.005)\end{array}$ & $\begin{array}{c}0.004 \\
(0.494)\end{array}$ & $\begin{array}{l}-0.253^{*} \\
(0.055)\end{array}$ & $\begin{array}{l}-0.337^{* * *} \\
(0.014)\end{array}$ & $\begin{array}{c}-0.491^{* * * *} \\
(0.001)\end{array}$ & 1.000 \\
\hline
\end{tabular}

Note: 1. Number of observations $=142.2 . *$, **, and *** denote significance beyond 10 percent, 5 percent, and 1 percent levels, respectively. 3 . Variable definitions: TRANSPA is a dummy variable of information transparency, which takes 1 if Level A, and 0 if Level C. TCRI is credit rating, SHARE is board shareholding, CHAIRM is CEO duality, BLOCK is shareholding of large shareholders, IND is the ratio of independent directors, and ASSET is firm size.

\section{Logistic Regression Result of Corporate Information Transparency and Construction of the Board}

Table 4 presents the logistic regression result of corporate information transparency and construction of the board. Based on the results of information disclosure rankings, this thesis classifies samples into Level A, Level B, and Level $\mathrm{C}$ to compare and analyze each group of samples. TRANSPA $A_{i, t}$ of the empirical result 1 of Model 1 represents its Level A as 1 and Level B as 0.TRANSPA $A_{i, t}$ of the empirical result 2 of Model 1 represents its Level B as 1 and Level C as 0. TRANSPA $A_{i, t}$ of the Empirical Result 3 of Model 1 represents its Level A as 1 and Level C as 0.

Table 4 indicates the follows:

1. The significant negative correlation between $T C R I_{i, t}$ and $T R A N S P A_{i, t}$ in empirical results 1 and 3 implies that the higher the ratings, the lesser the information disclosure and thus, the worse the information transparency. In other terms, the company would not disclose much information during financial crisis. 
2. Although the positive correlation between $S H A R E_{i, t}$ and $T R A N S P A_{i, t}$ in empirical results 1 and 3 is expected, it is not significant. However, in empirical result 2, TCRI $I_{i, t}$ and $T R A N S P A_{i, t}$ are significant negative correlated. This is because the intention of directors of companies with lower ratings and bigger shares to manipulate earnings for personal benefits reduces information transparency of such companies when their shares are bigger.

3. The significant negative correlation between $C_{\text {CHAIRM }}$ and $T_{R A N S P A}$ i,t in empirical results 2 and 3 indicates that CEO duality tends to lead to lower information transparency. As a result, hypothesis 2 is supported empirically.

4. The negative correlation between $B L O C K_{i, t}$ and $T R A N S P A_{i, t}$ of the empirical study of Model 1 is not significant, implying that there is no clear evidence that shareholdings of directors and large shareholders are correlated with information transparency. As a result, hypothesis 3 is not supported.

5. The significant positive correlation between $I N D_{i, t}$ and $T R A N S P A_{i, t}$ in empirical results 2 and 3 is expected. However, it is insignificant in result 1 . This is because the higher the ratings of a company, the better its management, and as a result, the function of $I N D_{i, t}$ lessens. Moreover, as shown in empirical results 2 and 3, companies with lower ratings have more seats for independent directors and better management. Thus, hypothesis 4 is supported empirically.

6. Empirical result 3 is the best in the empirical study of overall model fitness of Model 1, possibly since $\operatorname{TRANSPA}_{i, t}$ of empirical result 3 is the comparison between the samples of Range A and Range C. The large difference enables easy detection of the connection between information transparency and construction of the board.

To conclude, information transparency is lower when the CEO also holds the position of the chairperson of the board, that is, the higher the number of independent directors, the greater the information transparency. Furthermore, information transparency of a company will remain unaffected no matter whether the stocks are held by the directors or major holders.

Table 4: Logistic Regression Result of Corporate Information Transparency and Construction of the Board

\begin{tabular}{|c|c|c|c|c|c|c|c|}
\hline \multirow{2}{*}{ Variables } & \multirow{2}{*}{ Expected Sign } & \multicolumn{2}{|c|}{$\begin{array}{l}\text { Result } 1 \\
\end{array}$} & \multicolumn{2}{|c|}{ Result 2} & \multicolumn{2}{|c|}{ Result 3} \\
\hline & & Coefficients & Coefficients & Coefficients & p-value & Coefficients & p-value \\
\hline$T C R I_{i, t}$ & - & $-0.225^{*}$ & 0.096 & 0.031 & 0.181 & $-0.343^{*}$ & 0.064 \\
\hline$S H A R E_{i, t}$ & + & 0.012 & 0.148 & $-0.022^{*}$ & 0.081 & 0.015 & 0.139 \\
\hline CHAIRM $_{i, t}$ & - & -0.297 & 0.161 & $-0.393^{*}$ & 0.095 & $-0.579^{*}$ & 0.097 \\
\hline$B L O C K_{i, t}$ & + & -0.024 & 0.126 & -0.011 & 0.148 & -0.018 & 0.132 \\
\hline$I N D_{i, t}$ & + & 0.121 & 0.237 & $2.839^{* *}$ & 0.019 & $5.525^{\text {**** }}$ & 0.007 \\
\hline$S I Z E_{i, t}$ & + & 0.178 & 0.127 & 0.158 & 0.116 & $0.647^{* *}$ & 0.020 \\
\hline Constant & & -2.770 & 0.153 & -1.274 & 0.164 & $-9.368^{* *}$ & 0.044 \\
\hline \multicolumn{2}{|c|}{ Number of Observations } & 279 & & 261 & & 142 & \\
\hline \multicolumn{2}{|c|}{ Cox \& Snell R Square } & 0.228 & & 0.269 & & 0.324 & \\
\hline p-value & & 0.125 & & 0.088 & & 0.020 & \\
\hline
\end{tabular}

Note: 1. TRANSPA is a dummy variable of information transparency. Result 1 of Model 1 represents its Level A as 1 and Level B as 0 . Result 2 of Model 1 represents its Level B as 1 and Level C as 0. Result 3 of Model 1 represents its Level A as 1 and Level C as 0. 2. Variable definitions: TRANSPA is a dummy variable of information transparency, TCRI is credit rating, SHARE is board shareholding, CHAIRM is CEO duality, BLOCK is shareholding of large shareholders, IND is the ratio of independent directors, and ASSET is firm size. 3. *, **, and *** denote significance beyond 10 percent, 5 percent, and 1 percent levels, respectively.

\section{The Initial Return Rate of Convertible Bonds and Information Transparency}

\section{Pearson Correlation Analysis of Initial Return Rate of Convertible Bonds and Information Transparency}

To find out whether different levels of information transparency have a different effect on the initial return rate of convertible bonds, based on the information transparency disclosure rankings system of the Securities and Futures Institute, this thesis dissects the samples into three groups: Level A, Level B, and Level C. Tables 5-1, 5-2, and 5-3 are Pearson related analysis of the initial return rate of convertible bonds and company information transparency. The results of information transparency disclosure rankings of TRANSPA $i, t$ in Table 5-1 represents its 
Level A as 1 and Level B as 0; in Table 5-2, Level B is represented as 1 and Level C as 0; in Table 5-3, Level A is represented as 1 and Level $\mathrm{C}$ as 0 .

As expected, the negative correlation between $\operatorname{RETURN}_{i, t}$ and $T R A N S P A_{i, t}$ in Table 5-1 is significant, but becomes positive in Table 5-2 and thus, hypothesis 5 cannot be supported by empirical study in this part. As for the other variables, the significant positive correlation between $R E T U R N_{i, t}$ and $G R O W_{i, t}$ implies that companies with better growth opportunities or better managing achievements have higher initial return rate of convertible bonds. However, $S A L E_{i, t}$ is of significant negative correlation in Table 5-1 and Table 5-2, which indicates that higher the information transparency, lower the initial return rate of convertible bonds.

Table 5-1: Pearson Correlation Analysis of Initial Return Rate of Convertible Bonds and Information Transparency (TRANSPA is a dummy variable of information transparency, which takes 1 if Level $\mathrm{A}$, and 0 if Level B)

\begin{tabular}{|c|c|c|c|c|c|c|c|}
\hline & $R E T U R N_{i, t}$ & $\operatorname{TRANSPA}_{i, t}$ & MARKET $_{i, t}$ & $A G E_{i, t}$ & $G R O W_{i, t}$ & $S A L E_{i, t}$ & $L E V_{i, t}$ \\
\hline $\operatorname{RETURN}_{i, t}$ & 1.000 & & & & & & \\
\hline$T R A N S P A_{i, t}$ & $\begin{array}{l}-0.146^{*} \\
(0.089)\end{array}$ & 1.000 & & & & & \\
\hline MARKET $_{i, t}$ & $\begin{array}{l}-0.007 \\
(0.481)\end{array}$ & $\begin{array}{l}0.141^{*} \\
(0.098)\end{array}$ & 1.000 & & & & \\
\hline$A G E_{i, t}$ & $\begin{array}{l}-0.133 \\
(0.127)\end{array}$ & $\begin{array}{l}0.101 \\
(0.179)\end{array}$ & $\begin{array}{l}0.634^{* * *} \\
(<0.001)\end{array}$ & 1.000 & & & \\
\hline $\mathrm{GROW}_{i, t}$ & $\begin{array}{l}0.222^{* * *} \\
(0.020)\end{array}$ & $\begin{array}{l}-0.060 \\
(0.289)\end{array}$ & $\begin{array}{l}-0.083 \\
(0.221)\end{array}$ & $\begin{array}{l}-0.086 \\
(0.212)\end{array}$ & 1.000 & & \\
\hline$S A L E_{i, t}$ & $\begin{array}{l}-0.277^{* * * *} \\
(0.004)\end{array}$ & $\begin{array}{l}0.218^{* *} \\
(0.021)\end{array}$ & $\begin{array}{l}0.450^{* * * *} \\
(<0.001)\end{array}$ & $\begin{array}{l}0.477^{* * * *} \\
(<0.001)\end{array}$ & $\begin{array}{l}-0.124 \\
(0.126)\end{array}$ & 1.000 & \\
\hline$L E V_{i, t}$ & $\begin{array}{l}-0.248^{* * *} \\
(0.010)\end{array}$ & $\begin{array}{l}0.084 \\
(0.224)\end{array}$ & $\begin{array}{l}-0.059 \\
(0.290)\end{array}$ & $\begin{array}{l}-0.020 \\
(0.429)\end{array}$ & $\begin{array}{l}-0.331^{\text {**** }} \\
(0.001)\end{array}$ & $\begin{array}{l}0.339^{* *} \\
(0.001)\end{array}$ & 1.000 \\
\hline
\end{tabular}

Note: 1 . Number of observations $=279.2{ }^{*}, * *$, and $* * *$ denote significance beyond 10 percent, 5 percent, and 1 percent levels, respectively. 3 . Variable definitions: RETURN is initial return rate of convertible bonds; TRANSPA is a dummy variable of information transparency, which takes 1 if Level A, and 0 if Level B; MARKET is public offering market; $A G E$ is establishment time; GROW is growth opportunities; SALE is firm size; and $L E V$ is financial leverage.

Table 5-2: Pearson Correlation Analysis of Initial Return Rate of Convertible Bonds and Information Transparency (TRANSPA is a dummy variable of information transparency, which takes 1 if Level $\mathrm{B}$, and 0 if Level C)

\begin{tabular}{|c|c|c|c|c|c|c|c|}
\hline & $\operatorname{RETURN}_{i, t}$ & $\operatorname{TRANSPA}_{i, t}$ & $M A R K E T_{i, t}$ & $A G E_{i, t}$ & $G R O W_{i, t}$ & $S A L E_{i, t}$ & $L E V_{i, t}$ \\
\hline $\operatorname{RETURN}_{i, t}$ & 1.000 & & & & & & \\
\hline $\operatorname{TRANSPA}_{i, t}$ & $\begin{array}{l}0.212^{* *} \\
(0.027)\end{array}$ & 1.000 & & & & & \\
\hline MARKET $_{i, t}$ & $\begin{array}{l}-0.031 \\
(0.383)\end{array}$ & $\begin{array}{c}-0.222^{* *} \\
(0.015)\end{array}$ & 1.000 & & & & \\
\hline$A G E_{i, t}$ & $\begin{array}{c}-0.037 \\
(0.376)\end{array}$ & $\begin{array}{c}-0.283^{\text {**** }} \\
(0.004)\end{array}$ & $\begin{array}{l}0.553^{* * *} \\
(<0.001)\end{array}$ & 1.000 & & & \\
\hline$G R O W_{i, t}$ & $\begin{array}{l}0.181^{* *} \\
(0.046)\end{array}$ & $\begin{array}{l}0.165^{*} \\
(0.058)\end{array}$ & $\begin{array}{c}-0.134 \\
(0.131)\end{array}$ & $\begin{array}{l}-0.159^{*} \\
(0.059)\end{array}$ & 1.000 & & \\
\hline$S A L E_{i, t}$ & $\begin{array}{l}-0.159^{*} \\
(0.066)\end{array}$ & $\begin{array}{c}0.029 \\
(0.391)\end{array}$ & $\begin{array}{l}0.462^{* * *} \\
(<0.001)\end{array}$ & $\begin{array}{l}0.401^{* * * *} \\
(<0.001)\end{array}$ & $\begin{array}{c}-0.107 \\
(0.160)\end{array}$ & 1.000 & \\
\hline$L E V_{i, t}$ & $\begin{array}{c}-0.224^{\text {*** }} \\
(0.017)\end{array}$ & $\begin{array}{l}-0.140^{*} \\
(0.096)\end{array}$ & $\begin{array}{c}0.079 \\
(0.236)\end{array}$ & $\begin{array}{l}-0.031 \\
(0.385)\end{array}$ & $\begin{array}{c}-0.221^{* * *} \\
(0.016)\end{array}$ & $\begin{array}{l}0.245^{* *} \\
(0.010)\end{array}$ & 1.000 \\
\hline
\end{tabular}

Note: 1 . Number of observations $=261.2 .^{*},{ }^{* *}$, and $* * *$ denote significant beyond 10 percent, 5 percent, and 1 percent levels, respectively. 3 . Variable definitions: RETURN is initial return rate of convertible bonds; TRANSPA is a dummy variable of information transparency, which takes 1 if Level B, and 0 if Level C; MARKET is public offering market; AGE is establishment time; GROW is growth opportunities; SALE is firm size; and $L E V$ is financial leverage. 
Table 5-3: Pearson Correlation Analysis of Initial Return Rate of Convertible Bonds and Information Transparency (TRANSPA is a dummy variable of information transparency, which takes 1 if Level $\mathrm{A}$, and 0 if Level C)

\begin{tabular}{|c|c|c|c|c|c|c|c|}
\hline & $\operatorname{RETURN}_{i, t}$ & $\operatorname{TRANSPA}_{i, t}$ & $M A R K E T_{i, t}$ & $A G E_{i, t}$ & $G R O W_{i, t}$ & $S A L E_{i, t}$ & $L E V_{i, t}$ \\
\hline $\operatorname{RETURN}_{i, t}$ & 1.000 & & & & & & \\
\hline $\operatorname{TRANSPA}_{i, t}$ & $\begin{array}{c}0.073 \\
(0.321)\end{array}$ & 1.000 & & & & & \\
\hline MARKET $_{i, t}$ & $\begin{array}{c}0.152 \\
(0.172)\end{array}$ & $\begin{array}{l}-0.101 \\
(0.264)\end{array}$ & 1.000 & & & & \\
\hline$A G E_{i, t}$ & $\begin{array}{c}0.063 \\
(0.345)\end{array}$ & $\begin{array}{l}-0.158 \\
(0.161)\end{array}$ & $\begin{array}{c}0.459^{* * *} \\
(0.001)\end{array}$ & 1.000 & & & \\
\hline $\operatorname{GROW}_{i, t}$ & $\begin{array}{l}-0.101 \\
(0.254)\end{array}$ & $\begin{array}{l}0.206^{*} \\
(0.097)\end{array}$ & $\begin{array}{c}0.060 \\
(0.351)\end{array}$ & $\begin{array}{l}-0.191 \\
(0.115)\end{array}$ & 1.000 & & \\
\hline$S A L E_{i, t}$ & $\begin{array}{l}-0.005 \\
(0.474)\end{array}$ & $\begin{array}{l}0.316^{* * *} \\
(0.020)\end{array}$ & $\begin{array}{c}0.471^{\text {*** }} \\
(0.001)\end{array}$ & $\begin{array}{c}0.488^{* * * *} \\
(0.001)\end{array}$ & $\begin{array}{l}-0.149 \\
(0.149)\end{array}$ & 1.000 & \\
\hline$L E V_{i, t}$ & $\begin{array}{c}-0.021 \\
(0.444)\end{array}$ & $\begin{array}{l}-0.050 \\
(0.389)\end{array}$ & $\begin{array}{c}0.218^{*} \\
(0.090)\end{array}$ & $\begin{array}{l}-0.031 \\
(0.431)\end{array}$ & $\begin{array}{l}-0.210^{*} \\
(0.092)\end{array}$ & $\begin{array}{l}0.466^{* * *} \\
(<0.001)\end{array}$ & 1.000 \\
\hline
\end{tabular}

Note: 1 . Number of observations $=142.2{ }^{*}, * *$, and $* * *$ denote significance beyond 10 percent, 5 percent, and 1 percent levels, respectively. 3 . Variable definitions: RETURN is initial return rate of convertible bonds; TRANSPA is a dummy variable of information transparency, which takes 1 if Level A, and 0 if Level C; MARKET is public offering market; $A G E$ is establishment time; GROW is growth opportunities; SALE is firm size; and $L E V$ is financial leverage.

\section{Regression of Initial Return Rate of Convertible Bonds and Information Transparency}

Table 6 presents the regression result of initial return rate of convertible bonds and information transparency. Based on information disclosure rankings result, this thesis dissects all samples into Level A, Level B, and Level $\mathrm{C}$ to analyze each group of samples. TRANSPA ${ }_{i, t}$ of the empirical result 1 of Model 1 represents its Level $\mathrm{A}$ as 1 and Level $\mathrm{B}$ as 0. TRANSPA $A_{i, t}$ of the empirical result 2 of Model 1 represents its Level $\mathrm{B}$ as 1 and Level $\mathrm{C}$ as 0. $T_{R A N S P A}$ i,t of the empirical result 3 of Model 1 represents its Level A as 1 and Level C as 0.

Table 6 shows the related results of initial return rate of convertible bonds and information transparency:

1. There is a negative but insignificant correlation between $T R A N S P A_{i, t}$ and $R E T U R N_{i, t}$ in empirical result 1 , which indicates that the correlation between companies with information rankings $\mathrm{A}$ or $\mathrm{B}$ and $R E T U R N_{i, t}$ is not very wide. However, there is a significant negative correlation between TRANSPA $i, t$ and $R E T U R N_{i, t}$ in empirical results 2 and 3, implying that for companies of lower rankings, there are fewer chances for stock price and revenue manipulation, which decrease the initial return rate of convertible bonds. This result is expected and thus, hypothesis 5 is supported empirically.

2. As for the other control variables, there is a significant positive correlation between $M A R K E T_{i, t}$ and $\operatorname{RETURN}_{i, t}$ in empirical results 1 and 3, which indicates that the market will affect the initial return rate of convertible bonds. GROW $W_{i, t}$ is of significant positive correlation under every empirical result of Model 2 , which indicates that higher the future growth possibilities, more willing are the investors to hold convertible bonds, which increase the initial return rate of convertible bonds.

3. However, $S A L E_{i, t}$ is of significant negative correlation under every empirical result since companies are required to disclose their previous month revenue condition before the $10^{\text {th }}$ of every month. The bigger the company, the more the attention and supervision it might get from the society and the government and thus, it will disclose more information. As a result, the convertible price of convertible bond would have been added up before open market operations and will become key when adjusting down the price.

To conclude, information transparency will indeed affect the initial return rate of convertible bonds. Higher the information transparency, lower the initial return rate of convertible bonds. 
Table 6: Regression of Initial Return Rate of Convertible Bonds and Information Transparency

\begin{tabular}{|c|c|c|c|c|c|c|c|}
\hline \multirow{3}{*}{ Variables } & \multirow{3}{*}{ Expected Sign } & \multirow{2}{*}{\multicolumn{2}{|c|}{ Result 1}} & \multirow{2}{*}{\multicolumn{2}{|c|}{ Result 2}} & \multirow{2}{*}{\multicolumn{2}{|c|}{ Result 3}} \\
\hline & & & & & & & \\
\hline & & Coefficients & p-value & Coefficients & p-value & Coefficients & p-value \\
\hline Constant & & $18.432^{* *}$ & 0.034 & $13.627^{*}$ & 0.069 & $19.167^{*}$ & 0.059 \\
\hline TRANSPA $_{i, t}$ & - & -1.445 & 0.147 & $-3.137^{* *}$ & 0.018 & $-3.317^{*}$ & 0.067 \\
\hline$M A R K E T_{i, t}$ & + & $2.375^{*}$ & 0.062 & 1.247 & 0.151 & $3.127^{*}$ & 0.054 \\
\hline$A G E_{i, t}$ & - & -0.188 & 0.122 & 0.057 & 0.217 & 0.053 & 0.291 \\
\hline$G R O W_{i, t}$ & + & $0.670^{*}$ & 0.051 & $0.516^{*}$ & 0.097 & $1.277^{*}$ & 0.091 \\
\hline$S A L E_{i, t}$ & + & $-0.918^{* *}$ & 0.038 & $-0.887^{* *}$ & 0.043 & $-1.090^{*}$ & 0.089 \\
\hline$L E V_{i, t}$ & - & 0.062 & 0.118 & $0.069^{*}$ & 0.079 & -0.004 & 0.321 \\
\hline \multicolumn{2}{|c|}{ Number of Observations } & 279 & & 261 & & 142 & \\
\hline \multirow{2}{*}{\multicolumn{2}{|c|}{ Adj $R^{2}$}} & 0.096 & & 0.062 & & 0.058 & \\
\hline & & 0.047 & & 0.038 & & 0.022 & \\
\hline
\end{tabular}

Note: 1. TRANSPA is a dummy variable of information transparency. Result 1 of Model 1 represents its Level A as 1 and Level B as 0 . Result 2 of Model 1 represents its Level B as 1 and Level C as 0 . Result 3 of Model 1 represents its Level A as 1 and Level $\mathrm{C}$ as 0. 2. Variable definitions: RETURN is initial return rate of convertible bonds; TRANSPA is a dummy variable of information transparency, which takes 1 if Level A, and 0 if Level C; MARKET is public offering market; AGE is establishment time; GROW is growth opportunities; SALE is firm size; and $L E V$ is financial leverage. 3. *, **, and *** denote significance beyond 10 percent, 5 percent, and 1 percent levels, respectively.

\section{CONCLUSION}

Information transparency is a popular topic in capital markets. Under the system, the construction of the board can have a significant effect on the level of information disclosure of the company. Besides, with convertible bonds becoming increasingly popular, there is another issue of whether information transparency will affect the initial return rate of convertible bonds. The empirical study involved in this thesis results in the following conclusions.

\section{Information Transparency is Lower When the CEO Also Holds the Position of the Chairperson of the Board}

If the CEO also holds the position of the chairperson of the board, he or she might choose a policy that is advantageous to him on facing conflicts, thus harming the company. As a result, less information will be disclosed, resulting in lower information transparency.

\section{The More the Number of Independent Directors, The Higher the Information Transparency}

The higher the number of independent directors in a company, the higher its monitoring functions and better its management. Therefore, the company will be more willing to hire more independent directors to decrease information asymmetry. Information disclosure is an important method of decreasing information asymmetry. Thus, the higher the number of independent directors, the better the information transparency of the company.

\section{The Shareholdings of Directors and Large Shareholders will not affect the Information Transparency}

We did not find any positive correlation between information transparency and the shareholdings of directors and large shareholders. The higher the shareholdings of directors or large shareholders, the lower the rate of shareholdings of minor shareholders and the lower the pressure for the company to disclose its related information. As a result, the company will not disclose its related information very often to decrease the cost of information disclosure and thus, information transparency will be low.

\section{The Higher the Information Transparency, The Lower the Initial Return Rate of the Convertible Bonds}

Issuance of new discount bonds is intended to make up for the possible loss that the risk of information asymmetry might bring to the investors. We also found a negative correlation between information transparency and 
the initial return rate of convertible bonds that have the features of stocks. The higher the information transparency, the lower the initial return rate of convertible bonds, and vice versa.

In conclusion, the construction of the board, including the number of seats for the chairperson, managing director, and independent director will affect the information disclosure policy and information transparency of a company. Besides, the higher the information transparency of a company, the smaller the problem of information asymmetry for inside and outside users and thus, the initial return rate of convertible bonds will be lower. This thesis uses the evaluation result of information disclosure rankings system as the proxy variable for evaluating corporate information transparency. It is intended that the follow-up study would use multiple indexes to evaluate information transparency to further refine our research.

\section{AUTHOR INFORMATION}

Tsing-Zai Wu is a professor in Department of Accounting, National Cheng Kung University, No.1, University Road,

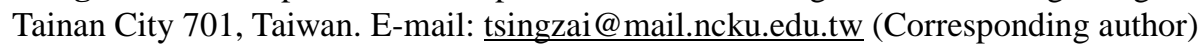

Pin-Sheng Lee is a candidate for the PhD in Accounting, National Cheng Kung University, No.1, University Road, Tainan City 701, Taiwan. E-mail: mail@psl.tw

\section{REFERENCES}

1. Adams, M., Thornton, B., \& Hall, G. (2008). IPO pricing phenomena: Empirical evidence of behavioral biases. Journal of Business \& Economics Research, 6(4), 67-74.

2. Agathee, U. S., Brooks, C., \& Sannassee, R. V. (2012). Hot and cold IPO markets: The case of the stock exchange of mauritius. Journal of Multinational Financial Management, 22(4), 168-192.

3. Aggarwal, R. K., Krigman L., \& Womack, K. L. (2002). Strategic IPO underpricing, information momentum, and lockup expiration selling. Journal of Financial Economics, 66(1), 105-137.

4. Attig, N., Ghoul, S. E., \& Guedhami, O. (2009). Do multiple large shareholders play a corporate governance role? Evidence from East Asia, Journal of Financial Research, 32(4), 395-422.

5. Ball, R., Kothari, S. P., \& Robin, A. (2000). The effect of international institutional factors on properties of accounting earnings. Journal of Accounting and Economics, 29(1), 1-51.

6. Bliss, M. A. (2010). Does CEO duality constrain board independence? Some evidence from audit pricing. Accounting and Finance, 51(2), 361-380.

7. Cai, N., Helwege, J., \& Warga, A. (2007). Underpricing in the corporate bond market. Review of Financial Studies, 20(6), 2021-2046.

8. Cheung, Y. L., Connelly, J. T., Jiang, P., \& Limpaphayom, P. (2011). Does corporate governance predict future performance? Evidence from Hong Kong. Financial Management, 40(1), 159-197.

9. Cormier, D., Ledoux, M. J., Magnan, M., \& Aerts, W. (2010). Corporate governance and information asymmetry between managers and investors. Corporate Governance, 10(5). 574-589.

10. Eng, L. L., \& Mak, Y. T. (2003). Corporate governance and voluntary disclosure. Journal of Accounting and Public Policy, 22(4), 325-345.

11. Ferreira, D., Ferreira, M., \& Raposo, C. (2011). Board structure and price informativeness. Journal of Financial Economics, 99(3), 523-545.

12. Geletkanycz, M. A., \& Boyd, K. Y. (2011). CEO outside directorships and firm performance: A reconciliation of agency and embeddedness views. Academy of Management Journal, 54(2), 335-352.

13. Hermalin, B. E., \& Weisbach, M. S. (2012). Information disclosure and corporate governance. The Journal of Finance, 67(1), 195-233.

14. Ho, S. S. M., \& Wong, K. S. (2001). A study of the relationship between corporate governance structures and the extent of voluntary disclosure. Journal of International Accounting, Auditing and Taxation, 10(2), $139-152$.

15. Hsieh, W. L. (2011). Implied option value of convertible bond - a study of primary market of convertible bond in Taiwan. (Working Paper). Taiwan: National Chung Hsing University.

16. Ibbotson, R. G. (1975). Price performance of common stock new issues. Journal of Financial Economics, $2(3), 235-272$. 
17. Kang, S., \& Kim, Y. (2011). Does earnings management amplify the association between corporate governance and firm performance. International Business and Economics Research Journal, 10(2), 53-66.

18. Lin, Y. F., Yeh, Y. M. C., \& Yang, F. M. (2013). Supervisory quality of board and firm performance: A perspective of board meeting attendance. Total Quality Management \& Business Excellence, 25(1), 1-16.

19. Linck, J., Netter, J., \& Yang, T. (2008). The determinants of board structure. Journal of Financial Economics, 87(2), 308-328.

20. Ramdani, D., \& Witteloostuijn, W. A. (2010). The impact of board independence and CEO duality on firm performance: A ouantile regression analysis for Indonesia, Malaysia, South Korea and Thailand. British Academy of Management, 21(3), 607-627.

21. Ritter, J. R., \& Welch, I. (2002). A review of IPO activity, pricing, and allocations. The Journal of Finance, 57(4), 1795-1828.

22. Sharma, V. D. (2004). Board of director characteristics, institutional ownership, and fraud: Evidence from Australia. Journal of Practice \&Theory, 23(2), 105-177.

23. Yeh, Y. H., Su, Y. H., Ko, C. E., \& Lee, T. K. (2004). The effect of corporate governance on related party transaction. Review of Securities and Futures Markets, 15(4), 69-106. 


\section{NOTES}

